\title{
CHARACTERISATION OF SOLID AND LIQUID PINEAPPLE WASTE
}

\author{
Abdullah $^{\left.1^{*}\right)}$ and Hanafi Mat ${ }^{2)}$ \\ ${ }^{1)}$ Department of Chemical Engineering, Faculty of Engineering, Diponegoro University, \\ Jl. Prof. Soedarto, SH, Tembalang, Semarang 50239, Indonesia, Telp.(024)7460058 \\ ${ }^{*}$ Corresponding author: abd busairi@yahoo.com \\ ${ }^{2)}$ Department of Chemical Engineering, \\ Faculty of Chemical Engineering and Natural Resources Technology, University of Malaysia, \\ Karung Berkunci 791, 80990 Johor Bahru,Johor, Malaysia
}

\begin{abstract}
The pineapple waste is contain high concentration of biodegradable organic material and suspended solid. As a result it has a high $\mathrm{BOD}$ and extremes of $\mathrm{pH}$ conditions. The pineapple wastes juice contains mainly sucrose, glucose, fructose and other nutrients. The characterisation this waste is needed to reduce it by recycling to get raw material or for conversion into useful product of higher value added products such as organic acid, methane, ethanol, SCP and enzyme. Analysis of sugar indicates that liquid waste contains mainly sucrose, glucose and fructose. The dominant sugar was fructose, glucose and sucrose. The fructose and glucose levels were similar to each other, with fructose usually slightly higher than glucose. The total sugar and citric acid content were 73.76 and $2.18 \mathrm{~g} / \mathrm{l}$. The sugar content in solid waste is glucose and fructose was 8.24 and $12.17 \%$, no sucrose on this waste
\end{abstract}

Keywords: characterization, liquid pineapple waste, solid pineapple waste

\section{INTRODUCTION}

Food processing operation also uses enormous quantities of water which are consequently discharge as a polluted effluent. The waste are contain high concentration of biodegradable organic material and suspended solid. As a result it has a high BOD and extremes of $\mathrm{pH}$ conditions (Kroyer, 1991). The solid waste from pineapple canning process was estimated about 40 - $50 \%$ from fresh fruit as pineapple peals and core (Buckle, 1989). The pineapple canning process and wastes production was shown in figure 1.

If these wastes discharge to the environment untreated they could cause a serious environment problem. Beside their pollution and hazard aspects in many cases, food processing waste such as pineapple waste might have a potential for recycling to get raw material or for conversion into useful product of higher value added products, or even as raw material for other industries, or for use as food or feed after biological treatment (Chandapillai and Selvarajah, 1978).

This waste contains valuable components which are mainly sucrose, glucose, fructose and other nutrients (Sasaki, et al., 1991; Krueger et al., 1992). The first stage in the optimisation of waste reduction is to identify and characterised the wastes (solid and liquid) produced. The aim of this investigation was to examine the characteristic of solid and liquid pineapple waste.

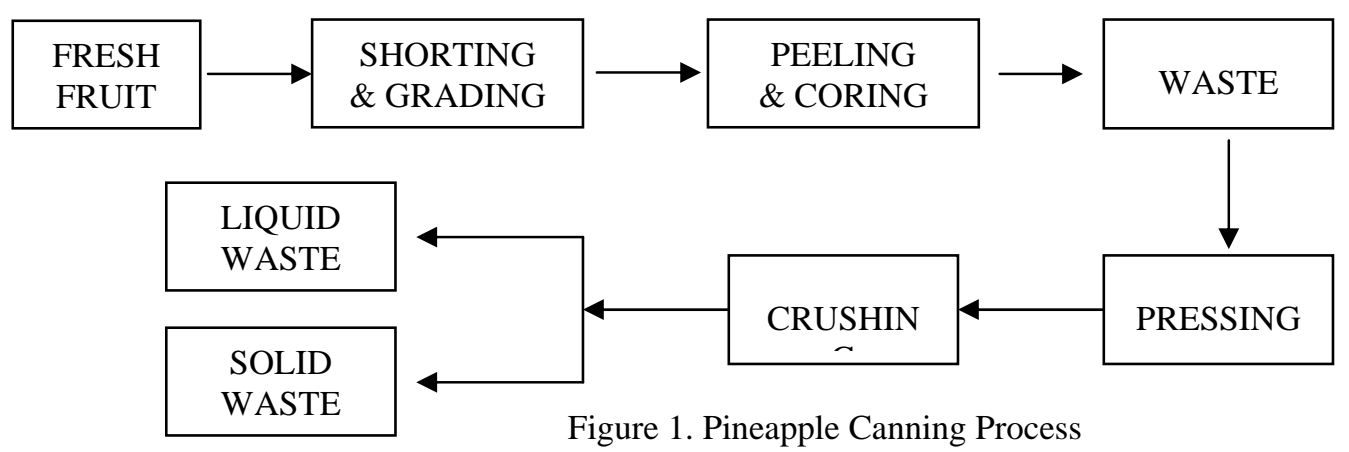




\section{MATERIALS AND METODS} Substrate

The solid and liquid pineapple waste obtained from Malaysian Cannery of Malaysia Sdn. Bhd. The liquid waste contained suspended particulate matter, before used the solution boiled for 5 minute resulting particulate flocks and settled rapidly upon cooling to room temperature and centrifuge at $4000 \mathrm{rpm}$ for 15 minute. The clear supernatant was determined the physical and chemical compositions (Lazaro, 1989). The solid waste was dried with oven at $55^{\circ} \mathrm{C}$ for a week, reduces the size by blender and then screened with screener (Lazaro, 1989; Bryan, 1990). To analyse the sugar content in solid waste by weighing $10 \mathrm{~g}$ sample, add $100 \mathrm{ml}$ alcohol and water (1:1) and weigh. Place in $80-85^{\circ} \mathrm{C}$ water bath for 25 minute and stir occasionally. Cool to room temperature and add alcohol to original weigh. Centrifuge 5 minute at 3500 rpm and filter through $0.45-0.7 \mu \mathrm{m}$. The filtrate was used to determine the sugar content in solid waste (Zygmunt, 1982).

\section{Methods \\ Liquid waste characterization}

The organic acid content in the sample was measured by HPLC (Waters TM 600). A 250 mmX4.6 mm ID Spherisob Octyl column (Waters) with UV detector $(210 \mathrm{~nm})$ were used. The eluent used was $0.2 \mathrm{M}$ phosphoric acid at flow rate of $0.8 \mathrm{ml}$ per minute and temperature of $25^{\circ} \mathrm{C}$.

The sugar content was also measured by the same HPLC, using a $300 \mathrm{~mm} \times 4 \mathrm{~mm}$ ID $\mu$ Bondapak/Carbohydrate column (Waters) with RI detector. The eluent used was a mixture of acetonitrile: water $(80: 20)$ at flow rate of $2 \mathrm{ml}$ per minute and temperature of $25^{\circ} \mathrm{C}$.

Reducing sugar was measured by Alkaline 3,5dinitrosalicilioc acid (DNS) method and total sugar was measured by hydrolyse non reducing sugar (sucrose) to reducing sugars (glucose and fructose), and determine by DNS method (Ceirwyn, 1995).

Cations were measured by using the Direct Air-Acetylene Flame method by using the Atomic Absorption Spectrometer (AAS) model PU 9200 and associated equipment supplied by Philips Company. The cations were determined by using AAS according to the standard method (Clesceri et al, 1989). Anions were measured by using the Ion Chromatography model LC20 with electric chemical detector ED40.

Total Nitrogen was measured by Kjeldahl method (Malaysian Standard, 1973). Soluble protein was measured by Lowry method (Ceirwyn, 1995). Phosphorus was measured by the molybdenum blue colorimetric method (Ceirwyn, 1995) and the $\mathrm{pH}$ was measured by the Cyberscan $1000 \mathrm{pH}$ meter supplied by the chemopharm Sdn, Bhd.

\section{Solid waste characterisation}

Moisture content, total solid, ash, fat, crude protein and fibre will be carried out according to Malaysian Standard (1973). To analyse the sugar content in solid waste by weighing $10 \mathrm{~g}$ sample, add $100 \mathrm{ml}$ alcohol and water (1:1) and weigh. Place in $80-85^{\circ} \mathrm{C}$ water bath for 25 minute and stir occasionally. Cool to room temperature and add alcohol to original weigh. Centrifuge 5 minute at 3500 rpm and filter through $0.45-0.7 \mu \mathrm{m}$. The filtrate was used to determine the sugar content in solid waste (Zygmunt, 1982).

\section{RESULTS AND DISCUSSION \\ The Characteristics of Liquid Pineapple Waste.}

The physical and chemical composition of pineapple waste juice can be seen in table 1 . Analysis of sugar indicates that liquid waste contains mainly sucrose, glucose and fructose. The dominant sugar was fructose, glucose and sucrose. The fructose and glucose levels were similar to each other, with fructose usually slightly higher than glucose. These result are similar to those for pineapple juice concentrate observed by Krueger (1992), but not similar was reported by Sasaki (1991) for pineapple waste juice indicates that the sucrose content higher than glucose and fructose smaller than glucose. The different of sugar composition might caused process to obtain this waste and also depend with season, area and pineapple canning factory. Analysis of soluble protein and total nitrogen were obtained 1.13 and 0.64 g/l, respectively. The waste contains very little nitrogen and soluble protein and elements such as Fe, $\mathrm{Ca}, \mathrm{Mn}, \mathrm{Zn}, \mathrm{Cu}, \mathrm{Cd}, \mathrm{Na}$, and $\mathrm{K}$, and potassium is the highest element in the pineapple waste. The ion chlor is higher than sulphate and nitrate, but the phosphate ion is nil.

The $\mathrm{pH}$ of pineapple waste is 4.0 , the $\mathrm{pH}$ of pineapple juice was reported by Moon (19) at range value 3.6-4.6, it similar which reported by Sasaki (1991). The total acidity is expressed as gram per litre of citric acid. Organic acid analysis by liquid chromatography indicates that most of the acidity is due to citric acid, with a significant contribution made by malic acid. Krueger (19927) has been reported that citric acid in pineapple juice is the dominant acid and the ratio was by ranged value from 1.8 to 8.2 . The value of acidity in pineapple waste was $2.95 \mathrm{~g} / \mathrm{l}$ with ratio of citric acid and malic acid was 7.1 . The major constituent of cation in pineapple waste is potassium at $526 \mathrm{mg} / \mathrm{l}$, it lower than the potassium content in pineapple juice have been reported by Krueger (1992) at range from 830 to $1410 \mathrm{mg} / \mathrm{l}$. 
Reaktor, Vol. 12 No. 1, Juni 2008, Hal. 48-52

Table 1. The Characteristics of Liquid Pineapple Waste

\begin{tabular}{|c|c|c|c|}
\hline Compositions & Parameters & This Work & Sasaki, 1991 \\
\hline \multirow{5}{*}{ Sugars } & Reducing sugar (g/l) & 40.40 & 39.20 \\
\hline & Sucrose (g/l) & 16.75 & 40.10 \\
\hline & Glucose (g/l) & 19.72 & 23.60 \\
\hline & Fructose (g/l) & 20.62 & 14.0 \\
\hline & Total Sugar (g/l) & 73.76 & 100.00 \\
\hline \multirow[t]{2}{*}{ Proteins } & Soluble protein (g/l) & 1.13 & 0.90 \\
\hline & Kjeldahl nitrogen (g/l) & 0.64 & 0.20 \\
\hline \multirow{3}{*}{ Organic acids } & Acidity, as citric acid (g/l) & 2.95 & - \\
\hline & Citric acid (g/l) & 2.18 & - \\
\hline & Malic acid (g/l) & 0.29 & - \\
\hline \multirow{9}{*}{ Cations } & Fe (mg/l ) & 3.30 & 5.43 \\
\hline & Ca (mg/l ) & 194.0 & 3.31 \\
\hline & Mn (mg/l ) & 3.60 & 13.97 \\
\hline & $\operatorname{Mg}(\mathrm{mg} / \mathrm{l})$ & 47.70 & 62.50 \\
\hline & Zn (mg/l ) & 5.80 & - \\
\hline & $\mathrm{Cu}(\mathrm{mg} / \mathrm{l})$ & 1.40 & 2.02 \\
\hline & Cd (mg/l ) & 0.00 & 0.00 \\
\hline & $\mathrm{Na}(\mathrm{mg} / \mathrm{l})$ & 294.0 & 8.61 \\
\hline & $\mathrm{K}(\mathrm{mg} / \mathrm{l})$ & 526.0 & - \\
\hline \multirow{5}{*}{ Anions } & $\mathrm{SO}_{4}^{-2}(\mathrm{mg} / \mathrm{l})$ & 25.60 & 169.7 \\
\hline & $\mathrm{PO}_{4}^{-3}(\mathrm{mg} / \mathrm{l})$ & 0.00 & 223.8 \\
\hline & $\mathrm{NO}_{3}{ }^{\mathrm{s}}(\mathrm{mg} / \mathrm{l})$ & 8.20 & - \\
\hline & $\mathrm{Cl}^{-1}(\mathrm{mg} / \mathrm{l})$ & 256.0 & - \\
\hline & Phosphorus (mg/l ) & 27.40 & - \\
\hline $\mathrm{pH}$ & & 4.30 & 4.00 \\
\hline
\end{tabular}

\section{The Characteristics of Solid Pineapple Waste.}

The composition of solid pineapple waste in this work and different author were given in table 2 . The moisture content of solid waste obtained was $87.5 \%$, the different of moisture content might be due the sample were obtained from various geographical origins and of varying degree of ripeness. Ash and phosphorus content is 4 and $0.1 \%$, it similar which reported by Chandapillai (1978) because the waste obtained from similar origin area (Johor). The nitrogen total content in waste is $0.9 \%$, it similar which has been reported by researcher previously. The sugar content in solid waste is glucose and fructose 8.24 and $12.17 \%$, no sucrose on this waste because during the drying process at $\mathrm{pH} 4.0$, the sucrose by inversion converted to glucose and fructose and degradation and polymerisation of sucrose resulting the glucose polymer with brown colour formation
(Chen, 1993). The highest of mineral constituent in the waste is potassium at $3 \%$, it similar with have been reported by researchers previously.

\section{CONCLUSIONS}

Analysis of sugar indicates that liquid waste contains mainly sucrose, glucose and fructose. The dominant sugar was fructose, glucose and sucrose. The fructose and glucose levels were almost similar with fructose slightly higher than glucose. The total sugar and citric acid content were 73.76 and $2.18 \mathrm{~g} / \mathrm{l}$. The sugar content in solid waste is glucose and fructose was 8.24 and $12.17 \%$, but no sucrose on this waste.

The chemical composition appears to be a good nutrient for cultivation of bacteria. It can potentially be used as carbon source for organic acid fermentation. 
Table 2. The characteristics of Solid Pineapple Waste

\begin{tabular}{|c|c|c|c|c|}
\hline Composition (\%) & This Work & Bardiya & Viswanath & Chandapillai \\
\hline Moisture & 87.50 & 92.80 & 87.69 & 89.70 \\
\hline Total solid & 12.50 & 7.80 & 12.31 & 10.30 \\
\hline Ash & 4.05 & 10.60 & 6.20 & 3.90 \\
\hline Organic carbon & - & 51.85 & 38.90 & - \\
\hline Total carbohydrates & - & 35.00 & - & - \\
\hline Reducing Sugar & 20.93 & - & - & - \\
\hline Glucose & 8.24 & - & - & - \\
\hline Fructose & 12.17 & - & - & - \\
\hline Sucrose & 0.00 & - & - & - \\
\hline Cellulose & - & 19.80 & - & - \\
\hline Crude Fibre & 10.57 & - & - & 14.70 \\
\hline Hemicellulose & - & 11.70 & - & - \\
\hline Total soluble & - & 30.00 & - & - \\
\hline Total nitrogen & 0.83 & 0.95 & 0.90 & 0.97 \\
\hline Crude Protein & 5.18 & - & - & 6.10 \\
\hline Fat & 0.15 & - & - & 0.20 \\
\hline Phosphorus & 0.14 & - & 0.08 & 0.10 \\
\hline $\mathrm{Fe}$ & 0.20 & - & - & - \\
\hline $\mathrm{Ca}$ & 0.26 & - & - & - \\
\hline $\mathrm{Mn}$ & 0.01 & - & - & - \\
\hline $\mathrm{Mg}$ & 0.40 & - & - & - \\
\hline $\mathrm{Zn}$ & 0.02 & - & - & - \\
\hline $\mathrm{Cu}$ & 0.03 & - & - & - \\
\hline $\mathrm{Cd}$ & 0.00 & - & - & - \\
\hline $\mathrm{Na}$ & 0.30 & - & - & - \\
\hline K & 3.00 & - & - & - \\
\hline $\mathrm{SO}_{4}^{-2}$ & 0.23 & - & - & - \\
\hline $\mathrm{PO}_{4}^{-3}$ & 0.00 & - & - & - \\
\hline $\mathrm{NO}_{3}{ }^{\mathrm{s}}$ & 0.06 & - & - & - \\
\hline $\mathrm{Cl}^{-1}$ & 0.38 & - & - & - \\
\hline
\end{tabular}

\section{AKNOWLEDGEMENTS}

The authors would like to acknowledge the support from the University Technology of Malaysia for providing this research. This research was also supported by grant from the Ministry of Science, Technology and Environment, Goverment of Malaysia (IRPA Vot. 72057).

\section{REFERENCES}

Bardiya, N., Somayaji, D., and N. Khanna, (1996), "Biomethanation of Banana Peel and Pineapple Waste”, Bioresource Technology, 58, pp. 73-76.

Buckle, K.A., (1989), "Biotechnology Opportunities in Waste Treatment and Utilisation for The Food Industry", In Biotechnology and The Food Industry, Ed. Rogers P.L. Breach Science Publishers, New York, pp. 261-277.

Bryan, W.L., (1990), "Solid State Fermentation of Sugar in Sweet Surghum", Enzyme Microb. Technology, 12(6), pp. 437-442.
Ceirwyn, S.J., (1995), "Analytical Chemistry of Food", Blackie Academic \& Professional, London, pp. 84-125.

Chandapillai, M.M. and Selvarajah T., (1978), "The Potential Use of Agricultural Waste in Livestock Production in Malaysia", In Food and Agriculture Malaysia 2000, Ed. Chin H.F., Faculty of Agriculture UPM Malaysia, pp. 257-274.

Chen, C.P. and Chou, C.C. (!993), "Cane Sugar Handbook", $12^{\mathrm{tH}}$ Edition, John Wiley \& Sons Inc., New York, pp. 222-225 and 632-635.

Clesceri, L.S., Greenberg, A.E. and Trussell, R.R., (1989), "Standard Methods for_Examination of Water and Waste Water", American Public Health Association, New York.

Kroyer, G.T. (1991), "Food Processing Wastes”, In Bioconversion of Waste Material to Industrial Product. Ed. 
Krueger, D.A., Krueger, R.G. and Maciel. J., (1992), "Composition of Pineapple Juice", Journal International AOAC, 75(2), pp. 280-282.

Lazaro, M.J., (1989), "Liquid Chromatographic Determination of Acid and Sugar in Homolactic Cucumbar Fermentation”, Journal AOAC. 72(1), pp. 52-55.

Malaysian Standard, (1973), "Specification for Wheat Flour”, Standard Institution of Malaysia, pp. 12-19.

Sasaki, K., Noparatnaraphorn, N. and Nagai, S., (1991), "Use of Photosynthetic Bacteria for The Production of SCP and Chemicals from Agro
Industrial Waste", In Bioconversion of Waste Material to Industrial Product, Ed. Martin. A.M. Elviser Applied Science, London, pp. 225-233.

Viswanath, P., (1992), “Anaerobic Digestion of Fruit and Vegetable Processing Waste for Biogas Production”, Bioresource Technology, 40, pp. 43-48.

Zygmunt, L.C., (1982), "HPLC Determination of Mono and Disaccharides in Presweetened Cereals", Journal AOAC, 65(2), pp. 256-260. 